\title{
Stringent Complete Remission of Primary Plasma Cell Leukemia with Reduced-dose Bortezomib, Lenalidomide and Dexamethasone: A Case Report and Review of the Literature
}

\author{
Shuji Ueda ${ }^{1}$, Masahiko Kubo ${ }^{1}$, Noriko Matsuura ${ }^{1}$, Hitomi Matsunaga ${ }^{1}$, Seiko Kataoka ${ }^{1}$, \\ Tetsuo Maeda ${ }^{2}$, Yoshiaki Inui ${ }^{1}$, Sumio Kawata ${ }^{1}$ and Yuzuru Kanakura ${ }^{2}$
}

\begin{abstract}
Plasma cell leukemia (PCL) is an aggressive variant of multiple myeloma characterized by a high level of plasma cells circulating in the peripheral blood. The prognosis of PCL patients treated with conventional chemotherapy remains poor. Some reports have suggested that both bortezomib and lenalidomide are effective in treating PCL. We herein report a case of primary PCL in which the patient achieved stringent complete remission after receiving combination chemotherapy with reduced-dose bortezomib, lenalidomide and dexamethasone (VRd). This regimen was very effective, and no severe adverse events were observed. A reduceddose VRd regimen can be considered in PCL patients.
\end{abstract}

Key words: plasma cell leukemia, stringent complete remission, reduced-dose VRd therapy

(Intern Med 52: 1235-1238, 2013)

(DOI: 10.2169/internalmedicine.52.0001)

\section{Introduction}

Plasma cell leukemia (PCL) is a rare, yet aggressive form of multiple myeloma characterized by a high level of plasma cells circulating in the peripheral blood. PCL can be classified as either de novo 'primary PCL' or 'secondary PCL,' which is a leukemic transformation of multiple myeloma (1). The prognosis of PCL patients treated with conventional chemotherapy remains poor, with a median survival ranging from two to 12 months $(2,3)$. Autologous or allogenic stem cell transplantation is currently recommended for eligible patients with PCL, and long-term survival has occasionally been reported $(4,5)$. Both bortezomib and lenalidomide are approved for the treatment of advanced multiple myeloma. Recently, the efficacy of bortezomib was also observed in a series of patients with newly diagnosed or relapsed PCL (6-8). Some reports have suggested that lenalidomide is effective in patients with relapsed PCL (9-11). Bortezomib and lenalidomide have different mechanisms of anti-plasma cell dysplasia activity $(12,13)$. The synergistic effects of dexamethasone are observed with both bortezomib and lenalidomide $(12,13)$. We herein present a case of primary PCL in which the patient achieved stringent complete remission after receiving combination chemotherapy with reduced-dose bortezomib, lenalidomide and dexamethasone.

\section{Case Report}

A 49-year-old man was transferred to our institution with severe fatigue, dyspnea and multiple bone pain. On admission, a biochemical examination revealed hypercalcemia $(15.2 \mathrm{mg} / \mathrm{dL})$, an elevated creatinine level $(2.37 \mathrm{mg} / \mathrm{dL})$ and a low immunoglobulin level. The serum immunoglobulin levels of all isotypes were low. A peripheral blood count showed a hemoglobin level of $11.6 \mathrm{~g} / \mathrm{dL}$, a platelet count of $22.1 \times 10^{9} / \mathrm{L}$ and a white blood cell count of $25.9 \times 10^{9} / \mathrm{L}$. A peripheral blood smear revealed $42 \%$ plasma cells with a few cytoplasmic vacuoles, as shown in Figure. The bone marrow aspirate and a trephine biopsy showed infiltration of

${ }^{1}$ Department of Internal Medicine, Hyogo Prefectural Nishinomiya Hospital, Japan and ${ }^{2}$ Department of Hematology and Oncology, Osaka University Graduate School of Medicine, Japan

Received for publication December 26, 2012; Accepted for publication February 11, 2013

Correspondence to Dr. Shuji Ueda, ueda0904@hp.pref.hyogo.jp 


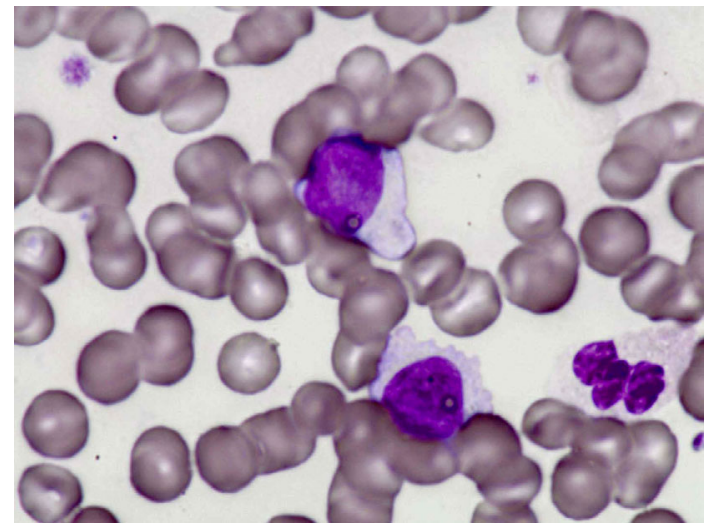

Figure. Peripheral blood smear showing marked prominence of plasma cells with a cytoplasmic vacuole (May-Giemza staining $\times \mathbf{1 , 0 0 0 )}$.

monoclonal plasma cells at a rate of $60.7 \%$. A flow cytometric analysis of the bone marrow aspirate revealed plasma cell phenotype positively for CD38, CD56, CD138 and cytoplasmic lambda light chain. A fluorescent in situ hybridization analysis revealed both CCND1/IGH gene fusion rearrangement and deletion of $13 \mathrm{q} 14.3$, while no abnormalities were found in a conventional cytogenetic analysis. Serum protein electrophoresis did not show any M proteins; however, urine electrophoresis demonstrated the presence of Bence Jones proteins of the lambda type. The $\beta_{2^{-}}$ microglobulin level was $6.4 \mathrm{mg} / \mathrm{L}$. A skeletal bone survey using X-rays demonstrated multiple lytic lesions in the vertebrae and skull. Based on the clinical and laboratory findings, the patient was diagnosed as having primary plasma cell leukemia. Following normalization of the calcium and creatinine levels with the administration of bisphosphonate, prednisolone and diuretic agents, induction chemotherapy (Vd therapy) with bortezomib $\left(1.3 \mathrm{mg} / \mathrm{m}^{2}\right.$ on days $1,4,8$ and 11 of a 21-day cycle) and dexamethasone (20 mg on days $1,4,8$ and 11) was initiated. After the first course of chemotherapy, the patient's bone pain dramatically reduced and his general health status improved. The treatment was repeated every three weeks. After the second cycle of $\mathrm{Vd}$ therapy, the urine Bence Jones proteins disappeared on immunofixation and the percentage of plasma cells in the bone marrow decreased from $60.7 \%$ to $3.7 \%$. The patient achieved a complete response. He experienced reversible peripheral neuropathy (grade 2, WHO classification), which is a well-documented side effect of bortezomib therapy. Due to the neurotoxicity, bortezomib was reduced to a dose of 1.3 $\mathrm{mg} / \mathrm{m}^{2}$ on days $1,8,15$ and 22 of a 35-day cycle (dexamethasone, $20 \mathrm{mg}$ on days 1, 8, 15 and 22). After the fourth cycle of $\mathrm{Vd}$ combination therapy, Bence Jones proteins were detected in the urine and a significant increase in the level of plasma cells in the bone marrow up to $17.1 \%$ was observed. Triple therapy with a combination of lenalidomide-VRd (bortezomib, $1.3 \mathrm{mg} / \mathrm{m}^{2}$ on days 1,8 and 15 ; lenalidomide, $10 \mathrm{mg} /$ day for 21 days; and dexamethasone, $20 \mathrm{mg}$ on days $1,8,15$ and 22 for a 28-day cycle) was then initiated. After the second course of VRd therapy, the percentage of plasma cells in the bone marrow decreased to $1.9 \%$ and urine serum immunofixation electrophoresis indicated the disappearance of Bence Jones proteins. A follow-up bone marrow assessment completed after the sixth course of VRd therapy showed an absence of phenotypically aberrant plasma cells in the bone marrow on multiparameter flow cytometry. The serum free kappa to lambda light chain ratio also normalized. The patient was in stringent complete remission without any severe adverse events based on the International Myeloma Working Group (IMWG) criteria. He underwent bone marrow stem cell transplantation from an HLA-matched unrelated donor with fludarabine $(150 \mathrm{mg} /$ $\mathrm{m}^{2}$ ), melphalan $\left(140 \mathrm{mg} / \mathrm{m}^{2}\right)$ and TBI (3 Gy) as a conditioning regimen. Twenty months after the PCL diagnosis, the patient remains in stringent $\mathrm{CR}$.

\section{Discussion}

Recent reports have indicated that new drugs, in particular, bortezomib and lenalidomide, can significantly improve the clinical course of PCL. A retrospective survey of 12 patients with PCL treated with bortezomib showed an initial response rate of $92 \%$ (8). Despite this dramatic initial efficacy, the duration of response to bortezomib was not long. Moreover, some reports have demonstrated the effectiveness of lenalidomide in patients with PCL; however the effects were also often temporary $(9,11)$. It has been suggested that dexamethasone exerts synergistic effects on both bortezomib and lenalidomide. Under this premise, it is believed that the most promising results can be obtained from a three-drug regimen consisting of bortezomib, lenalidomide and dexamethasone. In fact, bortezomib, lenalidomide and dexamethasone combination therapy (VRD regimen) is highly effective in the treatment of newly diagnosed myeloma (14). There have been only two case reports of PCL patients treated with VRD therapy $(15,16)$ (Table). One case was primary PCL and two cases were secondary PCL. Goyal et al. reported the first primary PCL patient who obtained a complete remission after receiving combination chemotherapy with bortezomib, lenalidomide and dexamethasone (15). However, the details of the treatment regimen and the patient's clinical course were not described. On the other hand, Gozzetti et al. reported two secondary PCL cases in detail (16). The two patients were treated with a VRD regimen and obtained complete remission. However, one patient developed grade 3 neutropenia and pneumonia. Due to therapy discontinuation, he suffered disease recurrence and thereafter died.

The VRD regimen currently used usually consists of 3week cycles of bortezomib at a dose of $1.3 \mathrm{mg} / \mathrm{m}^{2}$ (on days $1,4,8$ and 11), lenalidomide at a dose of $25 \mathrm{mg}$ (days 114) and dexamethasone (40 or $20 \mathrm{mg}$ on days $1,2,4,5,8$, 9, 11 and 12). However, peripheral neuropathy is one of the most critical toxicities of bortezomib and often leads to dose modification and drug discontinuation. Bortezomib-induced 
Table. 4 Cases of Plasma Cell Leukemia Treated with VRD(d) Therapy

\begin{tabular}{|c|c|c|c|c|c|c|}
\hline Case[Ref] & $\begin{array}{l}\text { Age/ } \\
\text { Sex }\end{array}$ & $\begin{array}{l}\text { Primary/ } \\
\text { Secondary } \\
\text { Ig class }\end{array}$ & $\begin{array}{c}\text { Treatment } \\
\text { Regimen }\end{array}$ & Response & $\begin{array}{c}\text { Severe } \\
\text { Side effect }\end{array}$ & Overall \\
\hline $1[15]$ & $40 / F$ & $\begin{array}{c}\text { Primary } \\
\text { BJP L }\end{array}$ & $\begin{array}{l}\text { Bortezomib } \\
\text { Lenalidomide } \\
\text { Dexamethasone } \\
\text { (not described } \\
\text { In detail) }\end{array}$ & $\begin{array}{l}\text { CR after } \\
4 \text { cycle }\end{array}$ & Not described & $\begin{array}{l}\quad \begin{array}{l}\text { Alive } \\
(+9 \mathrm{~m})\end{array} \\
\text { Followed by } \\
\text { Auto SCT }\end{array}$ \\
\hline $2[16]$ & $64 / \mathrm{M}$ & $\begin{array}{l}\text { Secondary } \\
\text { IgG k }\end{array}$ & $\begin{array}{l}\text { Bortezomib } \\
(1.3 \mathrm{mg} / \mathrm{m} 2 \text { day } 1,4,8,11) \\
\text { Lenalidomide } \\
\text { (25mg days } 1-14) \\
\text { Dexamethasone } \\
\text { (40mg days } 1,7,14,21)\end{array}$ & $\begin{array}{l}\text { CR after } \\
4 \text { cycle }\end{array}$ & $\begin{array}{l}\text { Neutropenia } \\
\text { (grade 3) } \\
\text { Pneumonia }\end{array}$ & $\begin{array}{l}\text { Died } \\
(7 \mathrm{~m})\end{array}$ \\
\hline 3 [16] & $71 / \mathrm{M}$ & $\begin{array}{l}\text { Secondary } \\
\text { IgG k }\end{array}$ & $\begin{array}{l}\text { Bortezomib } \\
(1.3 \mathrm{mg} / \mathrm{m} 2 \text { day } 1,4,8,11) \\
\text { Lenalidomide } \\
(25 \mathrm{mg} \text { days } 1-21) \\
\text { Dexamethasone } \\
\text { (40mg days } 1,2-4,5-8 \\
\quad 9-11,12)\end{array}$ & $\begin{array}{l}\text { CR after } \\
5 \text { cycle }\end{array}$ & Not described & $\begin{array}{l}\text { Alive } \\
\qquad(+12 \mathrm{~m}) \\
\text { Followed by } \\
\text { Lenalidomide } \\
\text { Maintenance }\end{array}$ \\
\hline $\begin{array}{c}\text { Present } \\
\text { Case }\end{array}$ & $49 / \mathrm{M}$ & $\begin{array}{l}\text { Primary } \\
\text { BJP L }\end{array}$ & $\begin{array}{l}\text { Bortezomib } \\
(1.3 \mathrm{mg} / \mathrm{m} 2 \text { day } 1,, 8,15) \\
\text { Lenalidomide } \\
(10 \mathrm{mg} \text { days } 1-21) \\
\text { Dexamethasone } \\
(20 \mathrm{mg} \text { days } 1,8,15,21)\end{array}$ & $\begin{array}{c}\text { CR after } \\
6 \text { cycle }\end{array}$ & none & $\begin{array}{l}\quad \begin{array}{l}\text { Alive } \\
(+20 \mathrm{~m})\end{array} \\
\text { Followed by } \\
\text { Allo SCT }\end{array}$ \\
\hline
\end{tabular}

peripheral neuropathy appears to be dependent on the dose and related to treatment exposure (17). A recent study reported that once-weekly bortezomib is equally effective to and better tolerated than the standard twice-weekly bortezomib when administered in combination chemotherapy with melphalan-prednisolone \pm thalidomide (18). The most frequently seen toxicity of lenalidomide is myelosuppression, which can usually be managed with dose reduction. A phase 2 trial of relapsed or refractory multiple myeloma patients showed that lower doses of lenalidomide $(15 \mathrm{mg})$ plus low-dose dexamethasone (40 mg weekly) significantly reduce the incidence of hematologic toxicities (from 15-30\% to $2-13 \%$ ), infections (from $20 \%$ to $8 \%$ ) and thromboembolism (from $20 \%$ to $5 \%$ ) (19). In relapsed or refractory multiple myeloma patients, long-term continuous treatment may be more important for achieving optimal efficacy than the initial response to both lenalidomide-containing regimens and bortezomib-containing regimens $(20,21)$. Discontinuation of chemotherapy due to adverse events can be lethal in patients with highly aggressive malignancies, such as plasma cell leukemia. Therefor, we chose reduced-dose bortezomib $\left(1.3 \mathrm{mg} / \mathrm{m}^{2}\right.$ on days 1,8 and 15$)$, lenalidomide (10 $\mathrm{mg}$ for 21 days) and dexamethasone (20 mg weekly) to prevent therapy discontinuation. The reduced-dose VRd therapy was very effective, and only grade 1 hematological toxicity (anemia) was observed. We conclude that the reduceddose VRd regimen is well-tolerated and effective and can be used in patients with plasma cell leukemia.

The authors state that they have no Conflict of Interest (COI).

\section{References}

1. Albarracin F, Fonseca R. Plasma cell leukemia. Blood Rev 25: 107-112, 2011.

2. Ramsingh G, Mehan P, Luo J, Vij R, Morgensztern D. Primary plasma cell leukemia: a Surveillance, Epidemiology, and End Results database analysis between 1973 and 2004. Cancer 115: 5734-5739, 2009.

3. Tiedemann RE, Gonzalez-Paz N, Kyle RA, et al. Genetic aberrations and survival in plasma cell leukemia. Leukemia 22: 10441052, 2008.

4. Drake MB, Iacobelli S, van Biezen A, et al. Primary plasma cell leukemia and autologous stem cell transplantation. Haematologica 95: 804-809, 2010.

5. Saccaro S, Fonseca R, Veillon DM, et al. Primary plasma cell leukemia: report of 17 new cases treated with autologous or allogeneic stem-cell transplantation and review of the literature. Am J Hematol 78: 288-294, 2005.

6. Capalbo S, Chiefa A, Delia M, Diomede D, Liso V. Effective combination therapy of bortezomib and dexamethasone for a plasma cell leukemia patient with multiple osteolytic lesions and extramedullary involvement. Acta Oncol 46: 262-264, 2007.

7. Katodritou E, Verrou E, Gastari V, Hadjiaggelidou C, Terpos E, Zervas K. Response of primary plasma cell leukemia to the combination of bortezomib and dexamethasone: do specific cytogenetic and immunophenotypic characteristics influence treatment outcome? Leuk Res 32: 1153-1156, 2008.

8. Musto P, Rossini F, Gay F, et al. Efficacy and safety of bortezomib in patients with plasma cell leukemia. Cancer 109: 22852290, 2007.

9. Benson DM Jr, Smith MK. Effectiveness of lenalidomide (Revlimid) for the treatment of plasma cell leukemia. Leuk Lymphoma 48: 1423-1425, 2007.

10. Guglielmelli T, Merlini R, Giugliano E, Saglio G. Lenalidomide, melphalan, and prednisone association is an effective salvage ther- 
apy in relapsed plasma cell leukaemia. J Oncol 2009: 867380, 2009.

11. Musto P, Pietrantuono G, Guariglia R, et al. Salvage therapy with lenalidomide and dexamethasone in relapsed primary plasma cell leukemia. Leuk Res 32: 1637-1638, 2008.

12. Hideshima T, Richardson $P$, Chauhan $D$, et al. The proteasome inhibitor PS-341 inhibits growth, induces apoptosis, and overcomes drug resistance in human multiple myeloma cells. Cancer Res 61: 3071-3076, 2001.

13. Mitsiades N, Mitsiades CS, Poulaki V, et al. Apoptotic signaling induced by immunomodulatory thalidomide analogs in human multiple myeloma cells: therapeutic implications. Blood 99: 45254530, 2002.

14. Richardson PG, Weller E, Lonial S, et al. Lenalidomide, bortezomib, and dexamethasone combination therapy in patients with newly diagnosed multiple myeloma. Blood 116: 679-686, 2010.

15. Goyal M, Mohammad N, Palanki SD, Vaniawala SN. Primary plasma cell leukemia with light chain secretion and multiple chromosomal abnormalities: How successfully treated? - A case report with review of literature. Indian J Med Paediatr Oncol 31: 96-100, 2010.

16. Gozzetti A, Musto P, Defina M, et al. Efficacy of bortezomib, lenalidomide and dexamethasone (VRD) in secondary plasma cell leukaemia. Br J Haematol 157: 497-498, 2012.

17. Richardson PG, Sonneveld P, Schuster MW, et al. Reversibility of symptomatic peripheral neuropathy with bortezomib in the phase III APEX trial in relapsed multiple myeloma: impact of a dosemodification guideline. Br J Haematol 144: 895-903, 2009.

18. Bringhen S, Larocca A, Rossi D, et al. Efficacy and safety of once-weekly bortezomib in multiple myeloma patients. Blood 116: 4745-4753, 2010.

19. Palumbo A, Bringhen S, Ludwig $H$, et al. Personalized therapy in multiple myeloma according to patient age and vulnerability: a report of the European Myeloma Network (EMN). Blood 118: 4519-4529, 2011.

20. Harousseau JL, Dimopoulos MA, Wang M, et al. Better quality of response to lenalidomide plus dexamethasone is associated with improved clinical outcomes in patients with relapsed or refractory multiple myeloma. Haematologica 95: 1738-1744, 2011.

21. Harousseau JL, Palumbo A, Richardson PG, et al. Superior outcomes associated with complete response in newly diagnosed multiple myeloma patients treated with nonintensive therapy: analysis of the phase 3 VISTA study of bortezomib plus melphalanprednisone versus melphalan-prednisone. Blood 116: 3743-3750, 2010.

(C) 2013 The Japanese Society of Internal Medicine http://www.naika.or.jp/imonline/index.html 